\title{
Application of Algerian Bentonite in the Removal of Cadmium (II) and Chromium (VI) from Aqueous Solutions
}

\author{
Mahfoud Barkat ${ }^{1}$, Salah Chegrouche ${ }^{*}$, Abdelhamid Mellah¹, Belgacem Bensmain ${ }^{2}$, \\ Djamel Nibou ${ }^{2}$, Makhlouf Boufatit ${ }^{3}$ \\ ${ }^{1}$ Centre de Recherche Nucléaire de Draria, Commissariat à l'Energie Atomique, Algiers, Algeria \\ ${ }^{2}$ Faculty of Mechanical and Process Engineering, University of Sciences and Technology Houari-Boumediene, \\ USTHB, Algiers, Algeria \\ ${ }^{3}$ Faculty of Chemistry, University of Sciences and Technology Houari-Boumediene, USTHB, Algiers, Algeria \\ Email: salahcheg@yahoo.fr
}

Received 13 April 2014; revised 12 May 2014; accepted 11 June 2014

Copyright (C) 2014 by authors and Scientific Research Publishing Inc.

This work is licensed under the Creative Commons Attribution International License (CC BY).

http://creativecommons.org/licenses/by/4.0/

(c) (i) Open Access

\section{Abstract}

The aim of this study is to report batch adsorption results of Cd (II) and $\mathrm{Cr}$ (VI) onto Algerian bentonite. The equilibrium adsorption process was achieved at about $120 \mathrm{~min}$ contact time. The kinetic and isotherms aspects of $\mathrm{Cr}$ (VI) and Cd (II) adsorption were investigated by varying operation parameters such as pH (0.5 - 6), initial Cd (II) and Cr (VI) concentrations (50 - $200 \mathrm{mg} / \mathrm{l})$ and temperature ( $293.15 \mathrm{~K}-343.15 \mathrm{~K})$. The optimum conditions obtained were: $\mathrm{pH}=6.0$ and 4.0 for Cd (II) and Cr (VI) respectively, initial concentrations of Cd (II) and $\mathrm{Cr}$ (VI) $=50 \mathrm{mg} / \mathrm{L}$ and T = 293.15 K. The kinetic of the adsorption process was studied by application of the most important kinetic models namely the pseudo-first order, the pseudo-second order and Elovich equations. The results showed that the pseudo-second order model fitted well the adsorption data of $\mathrm{Cr}$ (VI) whereas, and the Cd (II) adsorption data fitted best the Elovich equation. The equilibrium data fitted best the Langmuir isotherm, and the maximum adsorption capacity was determined through this model and was found to be 13.17 and $12.61 \mathrm{mg} / \mathrm{g}$ for Cd (II) and $\mathrm{Cr}$ (VI) respectively. The temperature had a reverse effect on the Cd (II) and $\mathrm{Cr}$ (VI) adsorption; our results showed that the removal efficiency increased to $82.4 \%$ and $55.70 \%$ for Cd (II) and $\mathrm{Cr}$ (VI) when the temperature decreased to $293.15 \mathrm{~K}$. The negative figures of the Gibbs free energy $\Delta G^{\circ}$ ads values range from $-15.23 \mathrm{~kJ} / \mathrm{mol}$ to $-14.37 \mathrm{~kJ} / \mathrm{mol}$ for Cd (II) and from $-9.70 \mathrm{~kJ} / \mathrm{mol}$ to $-9.64 \mathrm{~kJ} / \mathrm{mol}$ for $\mathrm{Cr}$ (VI) at 293.15 $\mathrm{K}$ to $343.15 \mathrm{~K}$ showed that the adsorption process is spontaneous and favourable. These results confirmed the ability of the low-cost Algerian natural bentonite to efficiently and competitively adsorb the two toxic elements investigated: cadmium (II) and chromium (VI).

\footnotetext{
${ }^{*}$ Corresponding author.

How to cite this paper: Barkat, M., Chegrouche, S., Mellah, A., Bensmain, B., Nibou, D. and Boufatit, M. (2014) Application of Algerian Bentonite in the Removal of Cadmium (II) and Chromium (VI) from Aqueous Solutions. Journal of Surface Engineered Materials and Advanced Technology, 4, 210-226. http://dx.doi.org/10.4236/jsemat.2014.44024
} 
Keywords

Adsorption, Cadmium, Chromium, Langmuir, Bentonite

\section{Introduction}

Many heavy metals have toxic effects at high concentration [1] [2]. Some of them, however, at trace level and under a specific valence play an important role as micronutrients in organisms

The presence of heavy metals such as cadmium and chromium in industrial wastewater and effluents has been a great concern due to their high toxicity and adverse accumulation characteristics [3] [4].

The most common oxidation states of chromium are trivalent $\mathrm{Cr}$ (III) and hexavalent $\mathrm{Cr}$ (VI)) which are invariably found in various industrial processes. Chromium (VI) compounds are much more toxic than Chromium (III) ones [5] [6]. The former are reported to be a powerful carcinogen capable of modifying the deoxyribonucleic (DNA) transcription process in both animals and humans which result in important chromosome aberrations [7]. It is, therefore, essential to remove $\mathrm{Cr}(\mathrm{VI})$ from wastewaters of electroplating, cement, leather tanning and paint industries which may contain up to hundreds of $\mathrm{mg} / \mathrm{L}$ of chromium though the tolerance limit of $\mathrm{Cr}$ (VI) for discharge into inland surface waters is only $0.1 \mathrm{mg} / \mathrm{L}$ and in waste water at the level of $0.05 \mathrm{mg} / \mathrm{l}$ [8] [9].

Cadmium (II) is a toxic inorganic pollutant with widely diffused emission sources, giving rise to a large scale environmental pollution. For these reasons, environmental severe regulations have been put up to limit the maximum cadmium concentration in natural water bodies as well as on the maximum allowed concentration for wastewater discharge [3]. Cadmium has been classified as a human carcinogen and teratogen affecting the lungs, the kidneys, the liver and the reproductive organs [1] [5]. The World Health Organization (WHO) has set a maximum guideline concentration of $0.003 \mathrm{mg} \cdot \mathrm{L}^{-1}$ for Cd in drinking water [10].

Several processes have been suggested to remove heavy metals such as chemical precipitation, ion exchange, reverse osmosis, [11] [12]. These methods are either expensive or inefficient especially when the concentrations of metal ions are less than $10 \mathrm{mg} / \mathrm{l}$.

In this study, we focused on the adsorption process, because it is inexpensive, widely applicable and has also been used in the water industry for the removal of colour, odour and organic matters [13]-[17].

The objective of the present study was to investigate the potential use of Algerian natural bentonite as a competitive adsorbent material for the removal of cadmium (II) and chromium (VI) from aqueous solutions. Batch experiments were carried out first, in order to determine an optimal contact time, then the influence of the most important parameters such as ( $\mathrm{pH}$, initial Cd (II) and $\mathrm{Cr}$ (VI) concentrations and temperature) was investigated. The Langmuir and Freundlich isotherm models were used to describe equilibrium data. The kinetic models of the Pseudo first-order, the second order-model and Elovich were applied to evaluate the mechanism of adsorption. The thermodynamic parameters derived from the Van't Hoff equation and the combination of the first and second law of thermodynamic (Gibbs free energy $\left(\Delta G^{\circ}\right)$, molar enthalpy $\left(\Delta H^{\circ}\right)$, and molar entropy $\left(\Delta S^{\circ}\right)$ were determined.

\section{Materials and Methods}

\subsection{Adsorbent}

Natural bentonite (98\% montmorillonite) from Maghnia (Western Algeria) used in this work was kindly supplied by ENOF (Entreprise Nationale des substances utiles et des produits non-ferreux). It was characterized by physicochemical analysis, by X-ray powder diffraction (XRD), by Infrared spectroscopy (FTIR) and scanning transmission microscopy (SEM). The apparent and true densities were determined by pycnometry method. The mean value of the $\mathrm{pH}$ was found to be 6.0 .

The chemical composition, the granulometric distribution and both densities of the bentonite are reported in Table 1.

\subsection{Preparation of Cr (VI) and Cd (II) Solutions and Sample Analysis}

All the chemicals used are of analytical grade. The stock solutions of $\mathrm{Cr}$ (VI) and Cd (II) are prepared by 
Table 1. Principal characteristics of our natural bentonite.

\begin{tabular}{cccccc}
\hline \multicolumn{2}{c}{ Chemical composition } & \multicolumn{2}{c}{ Granulometric distribution } & \multicolumn{2}{c}{ Densities } \\
\hline constituents & Contents $(\% \mathrm{w} / \mathrm{w})$ & Particle size $(\mathrm{mm})$ & Mass $(\%)$ & $d_{p}\left(\mathrm{~g} \cdot \mathrm{cm}^{-1}\right)$ & $d_{s}\left(\mathrm{~g} \cdot \mathrm{cm}^{-1}\right)$ \\
\hline $\mathrm{SiO}_{2}$ & 65.20 & $(0.200-0.165)$ & 5.75 & - & - \\
$\mathrm{Al}_{2} \mathrm{O}_{3}$ & 17.25 & $(0.165-0.125)$ & 5.23 & - & - \\
$\mathrm{Fe}_{2} \mathrm{O}_{3}$ & 2.10 & $(0.125-0.100)$ & 9.80 & - & 2.36 \\
$\mathrm{MgO}$ & 3.10 & $(0.100-0.063)$ & 29.99 & 1.04 & 2.34 \\
$\mathrm{CaO}$ & 1.20 & $(0.063-0.040)$ & 37.26 & 1.02 & 2.24 \\
$\mathrm{Na}_{2} \mathrm{O}$ & 2.15 & $(0.040-0.032)$ & 7.32 & 0.93 & 2.20 \\
$\mathrm{TiO}_{2}$ & 0.20 & $<0.032$ & 2.00 & 0.88 & 2.19 \\
$\mathrm{~K}_{2} \mathrm{O}$ & 0.60 & & & & \\
Ignition loss & 8.20 & & & & \\
\hline
\end{tabular}

$d_{p}=$ carbon packed density $\left(\mathrm{g} \cdot \mathrm{cm}^{-1}\right), d_{s}=$ carbon solid-phase density $\left(\mathrm{g} \cdot \mathrm{cm}^{-1}\right)$.

dissolving potassium dichromate $\left(\mathrm{K}_{2} \mathrm{Cr}_{2} \mathrm{O}_{7}\right)$ and $\mathrm{Cd}\left(\mathrm{NO}_{3}\right)_{2} \cdot 4 \mathrm{H}_{2} \mathrm{O}$ (Merck) salts in distilled water. Experimental solutions at the desired concentration were then obtained by successive dilutions. The initial $\mathrm{pH}$ adjustments were carried out either by $0.1 \mathrm{M}$ sulfuric acid or $0.1 \mathrm{M}$ sodium hydroxide.

The Cr (VI) and Cd (II) concentrations were determined by the inductively coupled plasma method, (ICP Jovin Yvon instrument). X-ray diffraction and infrared spectroscopy analysis were carried out, respectively; with Philips instrument PW 1730 and Beckman acculab 9 spectrophotometer. The $\mathrm{pH}$ values were determined by means of a Tacussel digital $\mathrm{pH}$ meter.

\subsection{Batch Experiments}

Adsorption studies were carried out using the batch technique to acquire the rate and the equilibrium data. The batch adsorption experiments were performed in mechanically agitated beakers containing $100 \mathrm{~mL}$ under constant conditions of pH 0.5 - 6.0, Cr (VI) and Cd (II) concentrations $50-200 \mathrm{mg} / \mathrm{L}$ and temperature $293.15 \mathrm{~K}$, $303.15 \mathrm{~K}, 313.15 \mathrm{~K}, 323.15 \mathrm{~K}, 333.15 \mathrm{~K}$ and $343.15 \mathrm{~K}$. Only one parameter was changed at a time while others were maintained constant during the experiments. Aqueous solutions with $200 \mathrm{mg} / \mathrm{L}$ of $\mathrm{Cr}$ (VI) and Cd (II) were prepared at a desired $\mathrm{pH}$ values and at $\mathrm{T}=293.15 \mathrm{~K}$. Adsorption isotherms onto natural bentonite (particle seize: (0.100 - $0.063 \mathrm{~mm}$ ) were obtained by mixing $100 \mathrm{ml}$ of a $200 \mathrm{mg} / \mathrm{l} \mathrm{of} \mathrm{Cr}(\mathrm{VI})$ and Cd (II) concentrations with an amount of bentonite ( $2.5 \mathrm{~g}$ ). The system was agitated at a constant stirring rate of $200 \mathrm{rpm}$, as for higher values the agitation has a strong negative effect [18]. After filtration, the residual Cd (II) and Cr (VI) concentrations were determined using ICP.

\subsection{Calculations}

The percentage removal of each metal ion was calculated using the following equation:

$$
R \%=\left(\left(C_{0}-C_{t}\right) / C_{0}\right) \times 100
$$

The distribution coefficient $K_{d}(\mathrm{~mL} / \mathrm{g})$ is calculated by the following equation:

$$
K_{d}=\left(\left(C_{0}-C_{t}\right) / C_{t}\right) v / m
$$

$K_{d}=$ amount of metal in adsorbent/amount of metal in solution $\times \mathrm{v} / \mathrm{m}(\mathrm{mL} / \mathrm{g})$

$C_{0}, C_{t}$ are respectively the initial and final metal concentration expressed in $\mathrm{mg} / \mathrm{L}$

Where $v$ is the volume of the solution $(\mathrm{mL})$ and $\mathrm{m}$ is the weight of the adsorbent (g) at equilibrium time.

The amount of metal ion sorbed at time $t, q$, was calculated from the mass balance equation: is represented by the expression

$$
q_{t}=\left(C_{0}-C_{t}\right) \cdot v / m
$$

$C_{0}, C_{t}$ are defined just above and $q_{t}$ is the adsorption capacity in $\mathrm{mg} / \mathrm{g}$ (milligram of solute per gram of adsorbent) where $t$ is equal to the equilibrium contact time, $C_{t}=C_{e}, q_{t}=q_{e}$, then the amount of metal ion sorbed at 
equilibrium, $q_{e}$.

All the adsorption experiments were carried out in duplicate. The errors in the data were typically less than $5 \%$.

\section{Theory}

\subsection{Equilibrium Isotherm Models}

Three models were used to fit the experimental data, Langmuir isotherm [19] and Freundlich isotherm [20].

\subsubsection{Langmuir Isotherm}

The Langmuir isotherm is based on assuming a monolayer sorption onto a surface with a fixed number of well defined sites; the equation is given below:

$$
1 / q_{e}=\left[\left(1 / Q_{0} b\right) \times\left(1 / C_{e}\right)+(1 / b)\right]
$$

where, $b$ is the adsorption equilibrium constant $\left(1 \cdot \mathrm{mg}^{-1}\right)$ related to the apparent energy of adsorption, $Q_{0}$ is the quantity of adsorbate required to form a single monolayer per unit mass of adsorbent $\left(\mathrm{mg} \cdot \mathrm{g}^{-1}\right)$, considered as the maximum adsorption capacity and $q_{e}$ is the amount adsorbed on unit mass of the adsorbent $\left(\mathrm{mg} \cdot \mathrm{g}^{-1}\right.$ ) when the equilibrium concentration is $C_{e}\left(\mathrm{mg} \cdot \mathrm{L}^{-1}\right)$.

A further analysis of the Langmuir equation can be made on the basis of a dimensionless parameter, $R_{L}$ [21], also known as the separation factor, given by Equation (5):

$$
R_{L}=1 /\left(1+b C_{e}\right)
$$

The values of $R_{L}$ indicate the type of Langmuir isotherm to be irreversible $\left(R_{L}=0\right)$, favourable $\left(0<R_{L}<1\right)$, linear $\left(R_{L}=1\right)$ or unfavourable $\left(R_{L}>1\right)$.

\subsubsection{Freundlich Isotherm}

The Freundlich adsorption isotherm is an empirical equation used to describe heterogeneous system. The linear form of Freundlich isotherm is represented as:

$$
q_{e}=K_{f} C_{e}^{1 / n}
$$

where, $K_{f}$ is the Freundlich constant, which indicates the relative adsorption capacity of the adsorbent related to the bonding energy, and $n$ is the heterogeneity factor representing the deviation from linearity of adsorption and is also known as Freundlich coefficient. The Freundlich coefficients can be determined by linear regression from the plot of $\log q_{e}$ versus $\log C_{e}$ on the basis of the linearized equation given by Equation (7)

$$
\log q_{e}=\log K_{f}+1 / n \log C_{e}
$$

The plot of $\log q_{e}$ as a function of $\log C_{e}$ at $293.15 \mathrm{~K}$ will lead us to determine the Freundlich constants $\left(K_{f}\right.$, $1 / n)$.

\subsection{Adsorption Kinetics}

In order to understand the mechanism of adsorption and potential rate controlling step, a number of kinetic models have been employed to test experimental data of CdII) and $\mathrm{Cr}(\mathrm{VI})$ adsorption. These include various ordered equations such as pseudo-first order equation [22], pseudo-second order equation [23], Elovich equation [24]. The conformity between experimental data and the model-predicted values was expressed by the correlation coefficients $r^{2}$. A relatively high $r^{2}$ value indicates that the model successfully describes the kinetics of adsorption of Cd (II) and Cr (VI).

\subsubsection{Pseudo-First- Order Kinetics}

The pseudo-first order model has been widely used to predict the metal adsorption kinetics. It was historically suggested by Lagergren in 1898 to deal with the adsorption of solid/liquid systems and it is expressed as:

$$
\mathrm{d} q_{e} / \mathrm{d} t=k_{1}\left(q_{e}-q_{t}\right)
$$


After integration and at the initial condition $q_{t}=0$ at $t=0$, it becomes:

$$
\log \left(q_{e}-q_{t}\right)=\log q_{e}-k_{1} t / 2.303
$$

where, $q_{e}$ and $q_{t}$ are the amounts of $\mathrm{Cr}(\mathrm{VI})$ and Cd (II) adsorbed (mg. $\mathrm{g}^{-1}$ ) at equilibrium time and at any instant of time $t$, and $k_{1}\left(1 \cdot \mathrm{min}^{-1}\right)$ is the rate constant of the pseudo first order adsorption. The plot of $\log \left(q_{e}-q_{t}\right)$ vs. $t$ gives a straight line for the first-order adsorption kinetics, which allow the computation of the adsorption rate constant, $k_{1}$.

\subsubsection{Pseudo-Second-Order Kinetics}

Ho's pseudo-second-order model has been successfully applied to the adsorption of metal ions, organic substances dyes [25]. It was expressed as:

$$
\mathrm{d} q_{t} / \mathrm{d} t=k_{2}\left(q_{e}-q_{t}\right)^{2}
$$

Integrating Equation (10) for the bounding conditions gives:

$$
1 / q_{t}=1 / k_{2} q_{e}^{2}+1 / q_{e}
$$

where $k_{2}\left(\mathrm{~g} \cdot \mathrm{mg}^{-1} \cdot \mathrm{min}^{-1}\right)$ is the second order rate constant of the pseudo-order adsorption and $h=k_{2} q_{e}^{2}$ is the initial adsorption rate.

\subsubsection{Elovich Kinetics Model}

The Elovich equation is of general application to chemisorption kinetics. It has been applied satisfactorily to some chemisorption processes and has been found to cover a wide range of slow adsorption rates [26]. The same equation is often valid for systems in which the adsorbing surface is heterogeneous, and is formulated as:

$$
\mathrm{d} q_{t} / \mathrm{d} t=\alpha \mathrm{e}^{-\beta q t}
$$

where, $\alpha\left(\mathrm{mg} \cdot \mathrm{g}^{-1} \cdot \mathrm{min}\right)$ is the initial adsorption rate and $\beta\left(\mathrm{mg}^{-} \mathrm{g}^{-1}\right)$ is the desorption constant related to the extent of the surface coverage and activation energy for chemisorption. Integrating Equation (12) for the bounding conditions gives:

$$
q_{t}=1 / \beta \ln (\alpha \beta)+1 / \beta \ln t
$$

\subsection{Thermodynamic Studies}

In order to determine the thermodynamic feasibility and the thermal effects of the sorption, the Gibbs free energy $\left(\Delta G^{\circ}\right)$, the molar entropy $\left(\Delta S^{\circ}\right)$ and the molar enthalpy $\left(\Delta H^{\circ}\right)$ were determined. The $\Delta G^{\circ}$ is the fundamental criterion to determine if a process occurs spontaneously. Data about the adsorbed Cd (II) and $\mathrm{Cr}$ (VI) at equilibrium at different temperatures have been used to evaluate the thermodynamic parameters $\Delta G^{\circ}, \Delta S^{\circ}$ and $\Delta H^{\circ}$ for the adsorption system by means of the following equations [27]:

$$
\text { Ln } k_{d}=\Delta S^{\circ} / R-\Delta H^{\circ} / R T
$$

where $T$ is temperature in Kelvin and $R$ is the universal gas constant $(8.31 \mathrm{~J} / \mathrm{mol} \cdot \mathrm{K})$

The plot of $L n k_{d}$ as a function of $1 / T$ should give a linear relationship with slope of $\Delta H^{\circ} / R$ and an intercept of $\Delta S^{\circ} / R$. Then, $\Delta G^{\circ}$ value was obtained at any temperature from the following equation:

$$
\Delta G^{\circ}=\Delta H^{\circ}-T \Delta S^{\circ}
$$

\section{Results and Discussion}

\subsection{Characterization of Adsorbent}

Some chemical and physical characteristics of natural bentonite are presented in Table 1.

From Table 1, it is clear that clay mineral was rich in various oxides.

\subsubsection{Analysis by DRX}

X-ray diffraction (XRD) analysis was carried out with X-ray diffractometer (Philips instrument PW 1730), using $\mathrm{CuK}_{\alpha}$ radiation. Patterns were recorded from $5^{\circ}$ to $70^{\circ} 2 \theta$ at a scan rate $1^{\circ} \mathrm{min}^{-1}$. The XRD patterns for the ben- 
tonite are shown in Figure 1.

Analysis by X-ray diffraction showed that the natural bentonite belongs to the montmorillonite clay family. It is characterized, respectively, by a series of big peaks at $\theta=5.78^{\circ}$ and $\mathrm{d}_{\mathrm{hkl}}=15.3 \mathrm{~A}, \theta=17.27^{\circ}$ and $\mathrm{d}_{\mathrm{hkl}}=5.13 \mathrm{~A}$, $\theta=19.9^{\circ}$ and $\mathrm{d}_{\mathrm{hkl}}=4.46 \mathrm{~A}$ and a few small peaks at $\theta=25.9^{\circ}$ and $\mathrm{d}_{\mathrm{hkl}}=33.3 \mathrm{~A}, \theta=49.2^{\circ}$ and $\mathrm{d}_{\mathrm{hkl}}=1.81 \mathrm{~A}$ which is characteristic of the presence a small amount of quartz.

\subsubsection{FTIR Spectral Analysis}

In order to determine which functional groups were responsible for metal uptake, an infrared analysis in solid phase was performed on bentonite in a KBr disk. An infrared spectrum was obtained for the adsorbent solid sample before the adsorption process. As illustrated in Figure 2, we can show the presence of absorption bands of clay phase and the adsorption characteristic bands of impurities.

Two absorption peaks are observed between 3200 and $3800 \mathrm{~cm}^{-1}$, and 1600 and $1700 \mathrm{~cm}^{-1}$. The first corresponds to the $\mathrm{OH}$ vibration band of silicate skeleton at $3290 \mathrm{~cm}^{-1}$, assigned by several authors to the montmorillonite mineral [28] [29]. The second peak at $1640 \mathrm{~cm}^{-1}$ showed the presence of absorbed water between the foils. Another intense peak appeared at $1000 \mathrm{~cm}^{-1}$, characterizing the main vibration bands of montmorillonite.

\subsubsection{Scanning Electronic Microscopy SEM}

All the samples were analyzed, examined and studied by means of Scanning electron microscope make PHILIPS ESEM XL 30 FEG. Figure 3 represents a microphotograph of the natural Algerian bentonite. The morphological analysis of the structure and the form of our material shows that our bentonite exists in aggregates, and in non uniform plate.

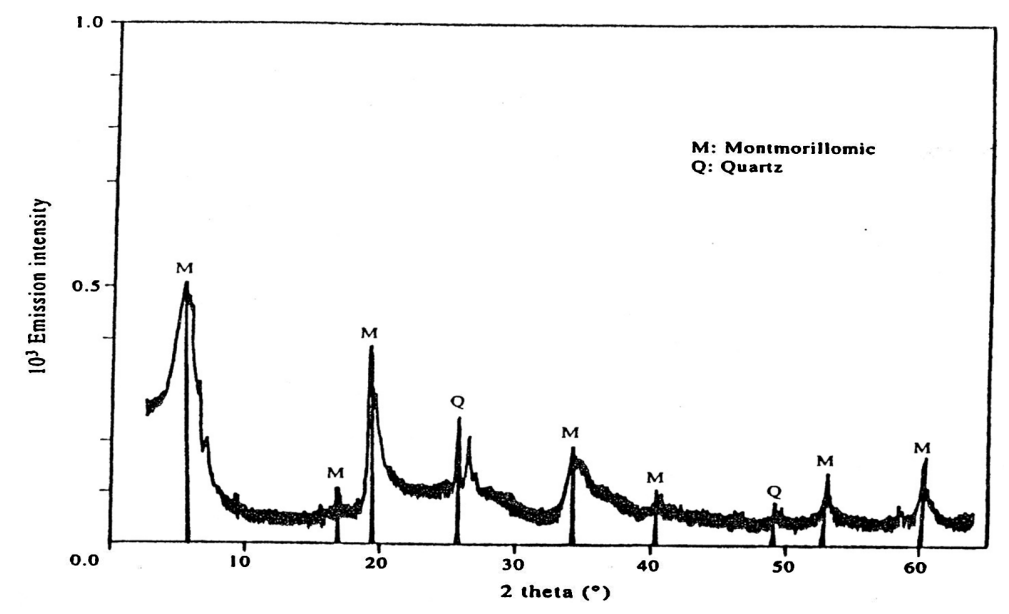

Figure 1. XRD pattern of natural Algerian bentonite.

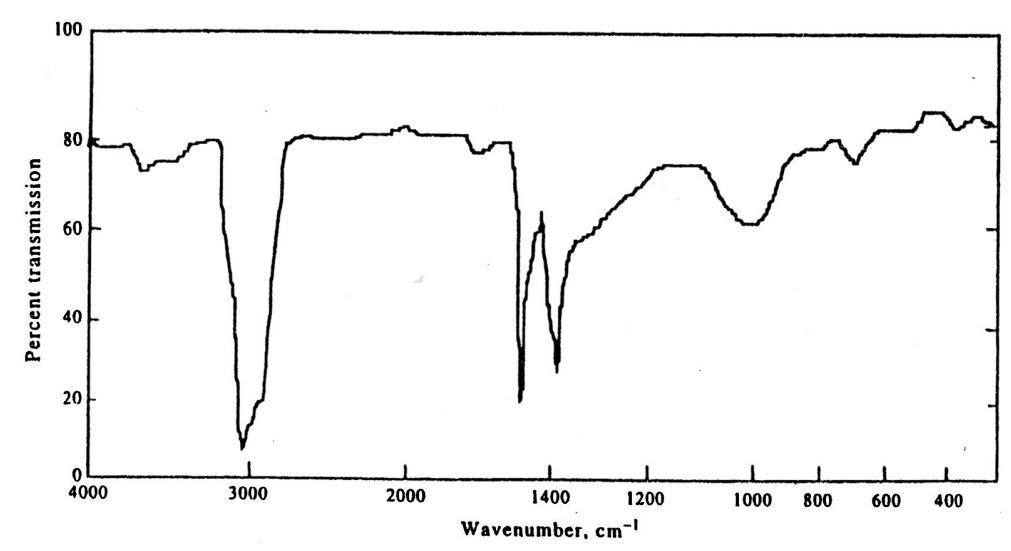

Figure 2. FTIR spectra of natural Algerian bentonite 


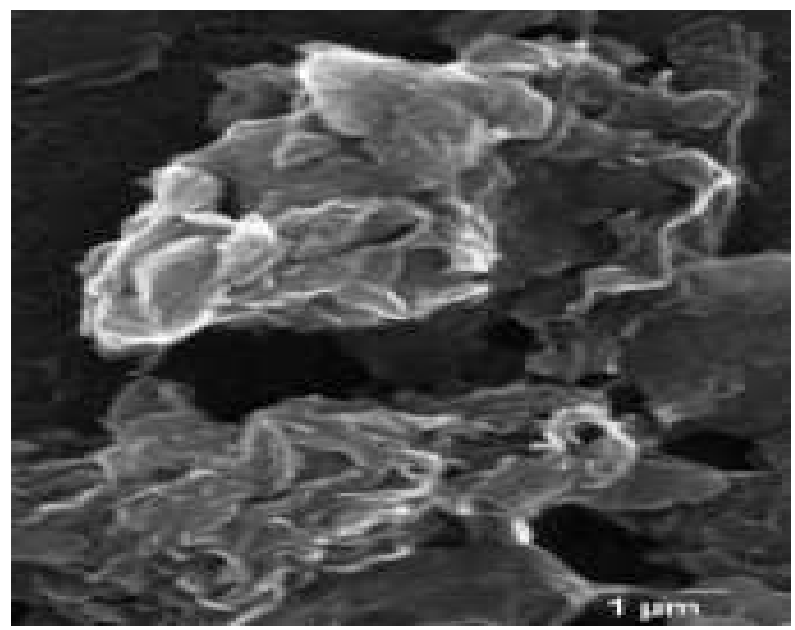

Figure 3. SEM image of the natural Algerian bentonite used in this study.

\subsection{Effect of Parameters on Adsorption Process}

Various parameters for the effective removal of Cd (II) and Cr (VI) from aqueous solutions by using Algerian bentonite as adsorbent were studied.

\subsubsection{Determination of the Optimum Contact Time}

The influence of contact time on adsorption of metal ions was investigated within the time range of 30 to 180 min at $20^{\circ} \mathrm{C}$. Table 2 listed our kinetic results at the following conditions: bentonite sample $=0.5 \mathrm{~g}$ with $50 \mathrm{ml}$ of Cd (II), Cr (VI) solutions and pH = 4). It was shown that the adsorption efficiency of Cd (II) and Cr (VI) ions increased with increasing contact time up to $120 \mathrm{~min}$ and later, it would remain constant. For instance, during 120 min, the adsorption efficiencies of Cd (II) and Cr (VI) ions reached 43.62 (II) \% and 28.45\% respectively. Therefore, the optimum contact time was fixed at $120 \mathrm{~min}$ for the further experiments. The results indicated that the equilibrium was reached slowly similar to the results reported by A. Zeid [30].

\subsubsection{Effect of $\mathrm{pH}$}

The $\mathrm{pH}$ of the solutions plays an important role in the adsorption process as the adsorbent surface acquires positive or negative charge in response to change in $\mathrm{pH}$ [31] [32]. The effect of $\mathrm{pH}$ on adsorption of Cd(II) and $\mathrm{Cr}(\mathrm{VI})$ ions was investigated by varying the $\mathrm{pH}$ from $0.5-6.0$ at different times. The effect on the uptake adsorption of Cd (II) and Cr (VI) is shown in Figure 4 and Figure 5.

It can be seen from Figure 4 and Figure 5, that the percent removal of $\mathrm{Cd}$ (II) and $\mathrm{Cr}$ (VI) ions on the adsorbent increased with increasing $\mathrm{pH}$ and significantly decreased at lower $\mathrm{pH}$ values. The minimal adsorption at low $\mathrm{pH}$ may be due to the higher concentration and high mobility of the $\mathrm{H}^{+}$, which were preferentially adsorbed rather than the metal ions [33]. It was found that the adsorption of $\mathrm{Cd}(\mathrm{II})$ and $\mathrm{Cr}(\mathrm{VI})$ ions was to be maximum at 6.0 and 5.0 respectively.

\subsubsection{Effect of Initial Cd(II) and Cr(VI) Concentrations}

The adsorption of Cd (II) and $\mathrm{Cr}$ (VI) ions onto bentonite as a function of the initial concentrations were studied in the concentration range of $50-200 \mathrm{mg} \cdot \mathrm{L}^{-1}$ while keeping all the other parameters constant. The results are shown in Figure 6 and Figure 7. It was clear that, the adsorption efficiencies increased when the metal ions concentrations decreased. For example, when Cd (II) and $\mathrm{Cr}$ (VI) ions concentrations increased from $50 \mathrm{mg} \cdot \mathrm{L}^{-1}$ to $200 \mathrm{mg} \cdot \mathrm{L}^{-1}$, the adsorption efficiencies decreased from $78.35 \%$ to $48.50 \%$ for $\mathrm{Cd}$ (II) and from $27.50 \%$ to $37.75 \%$ for $\mathrm{Cr}$ (VI). This may be explained by an increase in the number of Cd (II) and Cr (VI) ions to bind on the adsorbent surface and saturation of adsorbent surface with metal ions [25] [26]. Similar observations have been reported for $\mathrm{Cr}(\mathrm{VI})$ removal by using jatropha oil cake, sugarcane bagasse and maize corn cob [34] and Cd (II) onto untreated coffee grounds [35]. 


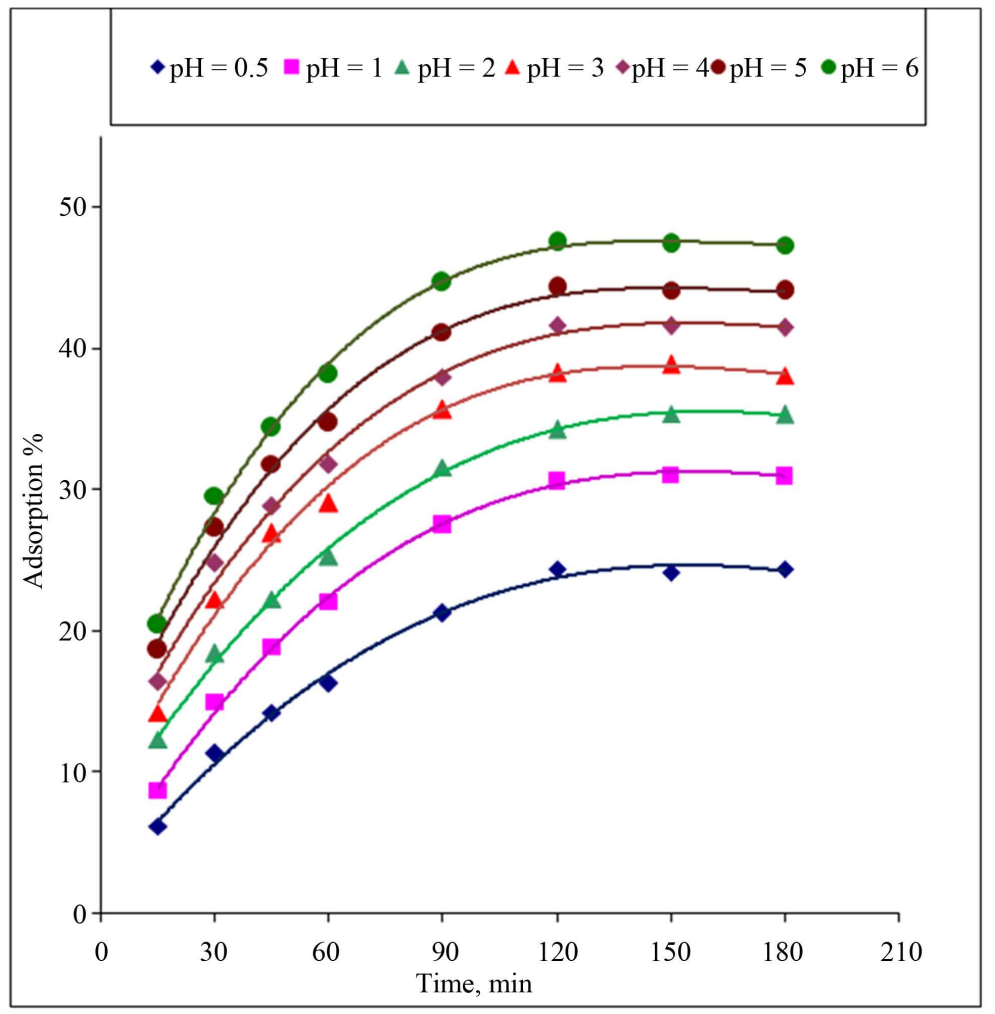

Figure 4. Effect of pH on the removal of Cd (II) at 293.15 K.

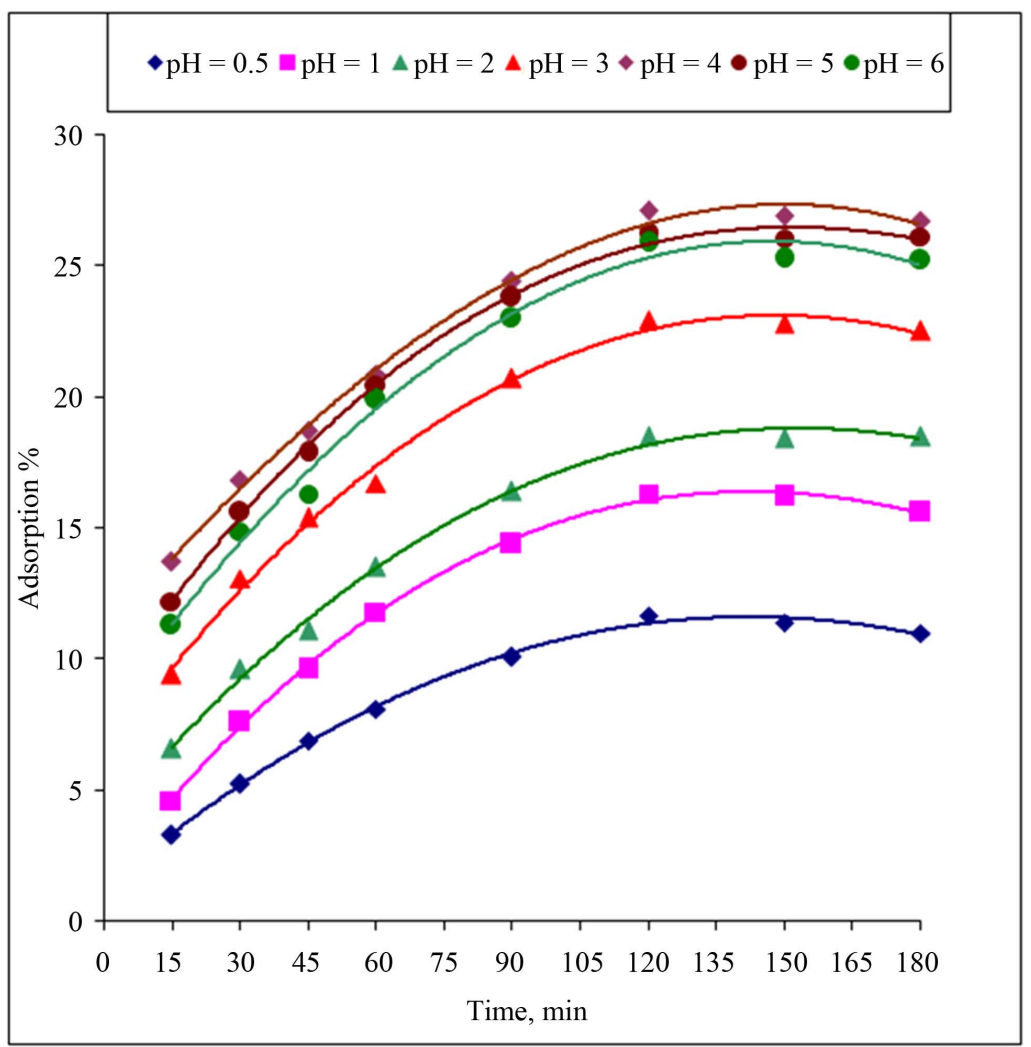

Figure 5. Effect of $\mathrm{pH}$ on the removal of $\mathrm{Cr}(\mathrm{VI})$ at $293.15 \mathrm{~K}$. 


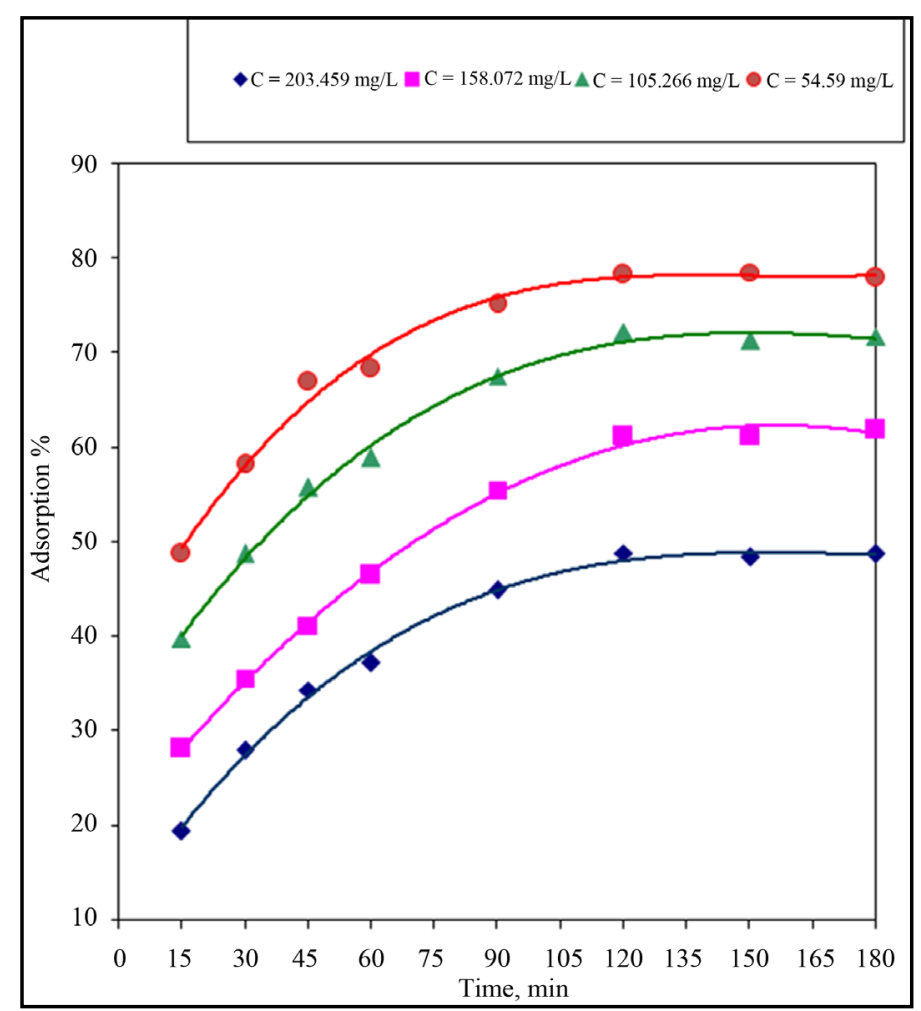

Figure 6. Effect of initial Cd (II) ions concentration on the adsorption at $293.15 \mathrm{~K}$.

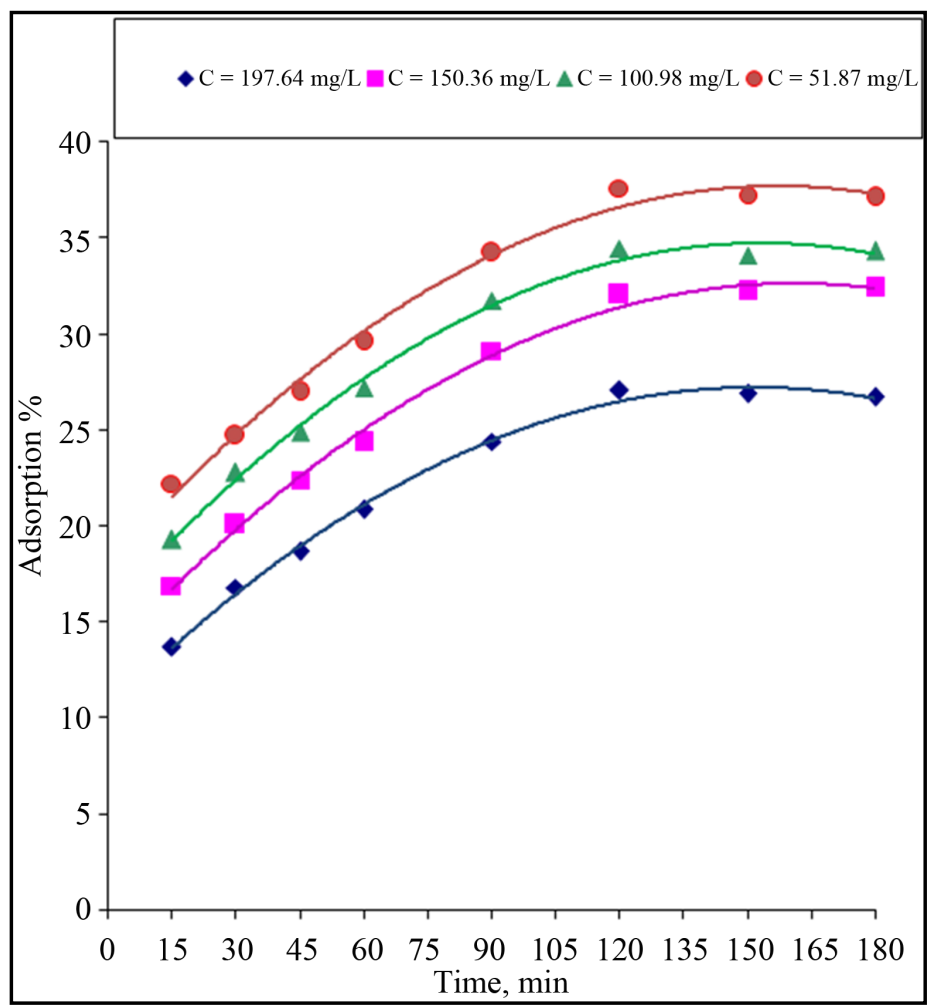

Figure 7. Effect of initial Cr (VI) ions concentration on the adsorption at $293.15 \mathrm{~K}$. 
Table 2. Effect of contact time on the rate of adsorption of Cd (II) and Cr (VI).

\begin{tabular}{ccc}
\hline Time (min) & R \% (Cd (II) & R \% (Cr (VI) \\
\hline 30 & 17.30 & 16.95 \\
60 & 25.10 & 22.50 \\
90 & 38.50 & 23.50 \\
120 & 43.62 & 28.45 \\
150 & 43.64 & 28.47 \\
180 & 43.65 & 28.46 \\
\hline
\end{tabular}

\subsubsection{Effect of Temperature}

The temperature dependence of $\mathrm{Cd}$ (II) and $\mathrm{Cr}$ (VI) adsorption by natural bentonite was studied with a constant metal ion concentration of $50 \mathrm{mg} \cdot \mathrm{L}^{-1}$ for different temperatures $(293.15 \mathrm{~K}, 303.15 \mathrm{~K}, 313.15 \mathrm{~K}, 323.15 \mathrm{~K}$, $333.15 \mathrm{~K}$ and $343.15 \mathrm{~K}$ ). The results of the studies are presented in Figure 8 and Figure 9 which showed that adsorption efficiencies of $\mathrm{Cd}(\mathrm{II})$ and $\mathrm{Cr}$ (VI) decreases with increase in temperature. For example, with increase in temperature from $293.15 \mathrm{~K}$ to $343.15 \mathrm{~K}$, the uptake adsorption decreased for Cd (II) from $82.75 \%$ to $52.50 \%$ and for $\mathrm{Cr}$ (VI) from $38.75 \%$ to $22.45 \%$. The decrease in percentage of adsorption with rise in temperature may be due to desorption caused by an increase in the available thermal energy [36]. Higher temperature induces higher mobility of the adsorbate causing desorption. This indicates that the adsorption process is spontaneous and exothermic in nature.

\subsection{Equilibrium Isotherm Models [37] [38]}

To examine the relationship between adsorbent and adsorbate at equilibrium, and to search for the maximum sorption efficiency of adsorbent, sorption isotherm models such as Langmuir and Freundlich isotherms have been applied for $\mathrm{Cd}(\mathrm{II})$ and $\mathrm{Cr}(\mathrm{VI})$ ions and represented in (Figures 10-13) respectively.

The values of the Langmuir parameters $\mathrm{Q}_{0}$, $\mathrm{b}$ and Freundlich parameters $\mathrm{K}_{\mathrm{f}}$, $\mathrm{n}$ and the calculated regression correlation coefficients were reported in Table 3.

The Langmuir constants $\mathrm{Q}_{0}$ and $\mathrm{b}$ showed in these results were determined by linear regression and found to be 13.17 and $4.1 \times 10^{2}, 12.61$ and $0.56 \times 10^{2}$ for $\mathrm{Cd}$ (II) and $\mathrm{Cr}$ (VI), respectively and the regression coefficients $\left(r^{2}=0.990\right.$ and 0.997$)$ suggest that the adsorption of Cd (II) and Cr (VI) can be modelled by Langmuir as well as Freundlich model with a slight preference to Langmuir. The adsorption process was also favourable according to Langmuir's dimensionless constant separation factor $(\mathrm{R}<1)$.

\subsection{Adsorption Kinetics [39] [40]}

Various sorption kinetics models have been used to describe the removal of metals from solution, whereas most often used are Lagergren pseudo-first order and pseudo-second order Elovich equations. For evaluating the sorption kinetics of $\mathrm{Cd}^{2+}$ ions, pseudo-first order, pseudo-second order and Elovich kinetics models were used to find fit of the experimental data. The results are given in Tables 4-6. The kinetic rate constants obtained from these models showed that the Elovich and pseudo-second order equations possess relatively the highest correlation coefficient values $(0.984-0.998)$ and $(0.989-0.978)$ as a function of increasing values of $\mathrm{pH}$ for $\mathrm{Cd}$ (II) and $\mathrm{Cr}(\mathrm{VI})$. Therefore, it can be concluded that the pseudo-second order model fitted well the adsorption data of $\mathrm{Cr}$ (VI) whereas, the Cd (II) adsorption data fitted best the Elovich equation.

\subsection{Thermodynamic Study [41] [42]}

In order to describe thermodynamic behaviour of the removal of Cd (II) and $\mathrm{Cr}$ (IVI) ions onto natural bentonite, thermodynamic parameters including the change in free energy, enthalpy and entropy were calculated from the general Equations (14) and (15).

The values of thermodynamic parameters were given in Table 7 . The negative value of heat of reaction $\Delta H^{\circ}$ indicated that the sorption is exothermic. On the other hand, the decrease in entropy $\Delta S^{\circ}$, showing that the metal ions were stable on the solid surface. The values of $\Delta G$ found were small and negative indicating that the adsorption of both metal ions onto natural bentonite was spontaneous. However, increasing temperature does not seem to significantly change $\Delta G$. 


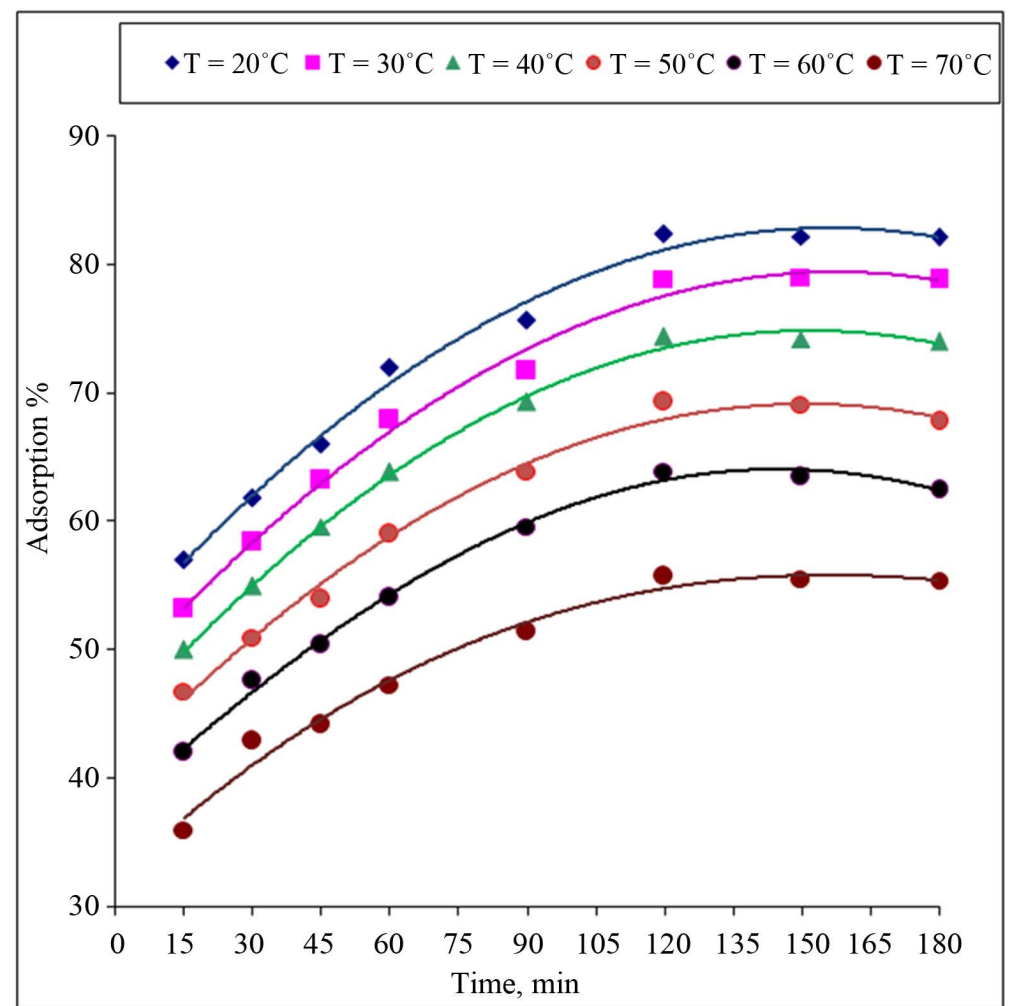

Figure 8. Effect of temperature on the adsorption of Cd (II).

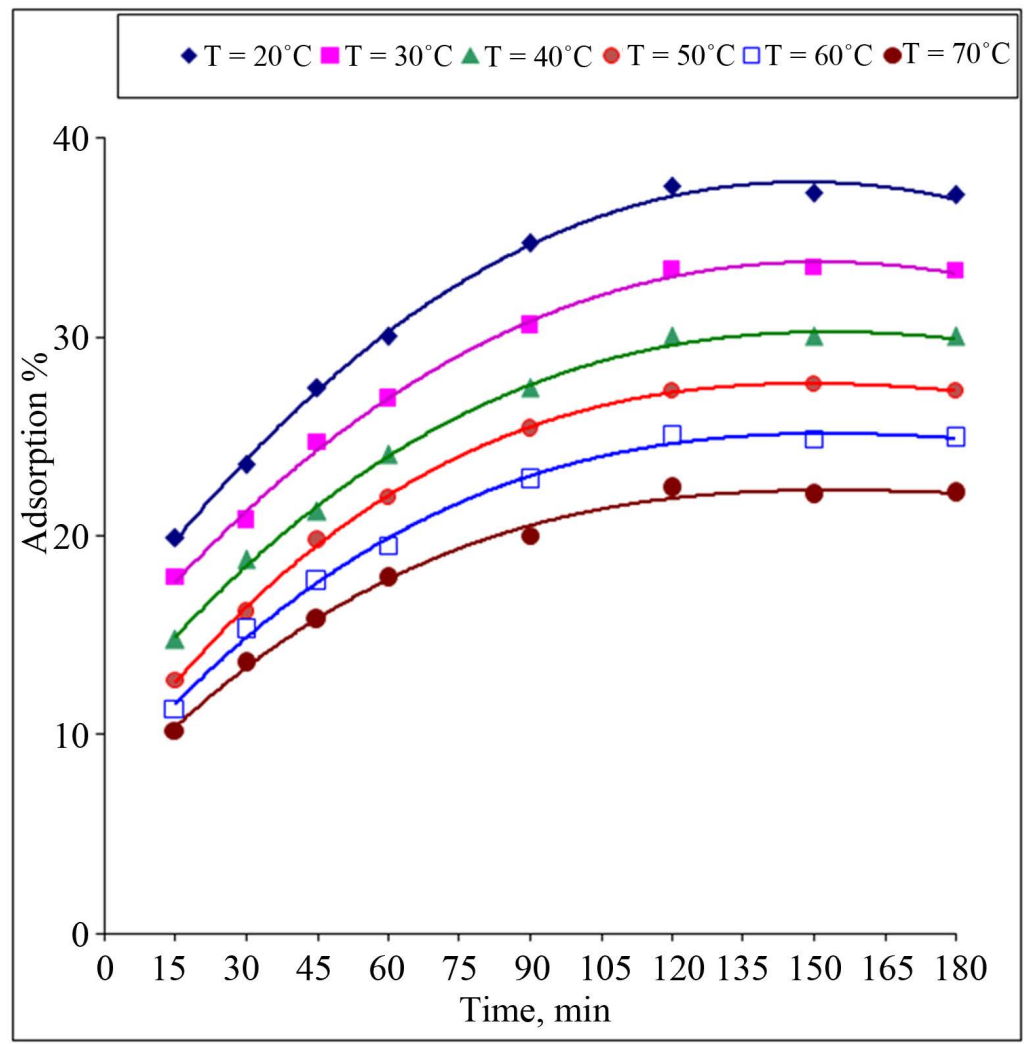

Figure 9. Effect of temperature on the adsorption of $\mathrm{Cr}$ (VI). 


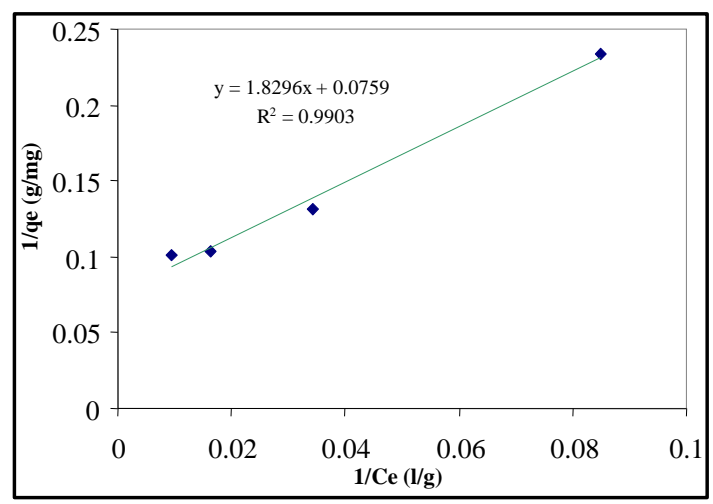

Figure 10. Langmuir Adsorption isotherm of Cd (II) onto natural bentonite at $293.15 \mathrm{~K}$.

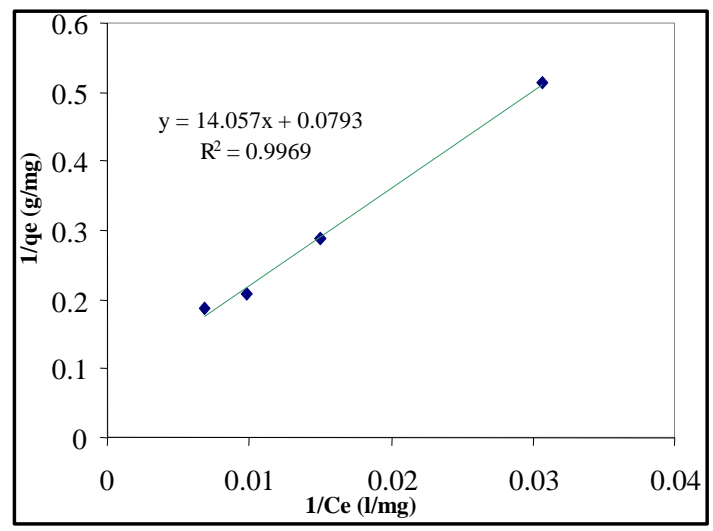

Figure 11. Langmuir Adsorption isotherm of Cr (VI) onto natural bentonite at $293.15 \mathrm{~K}$.

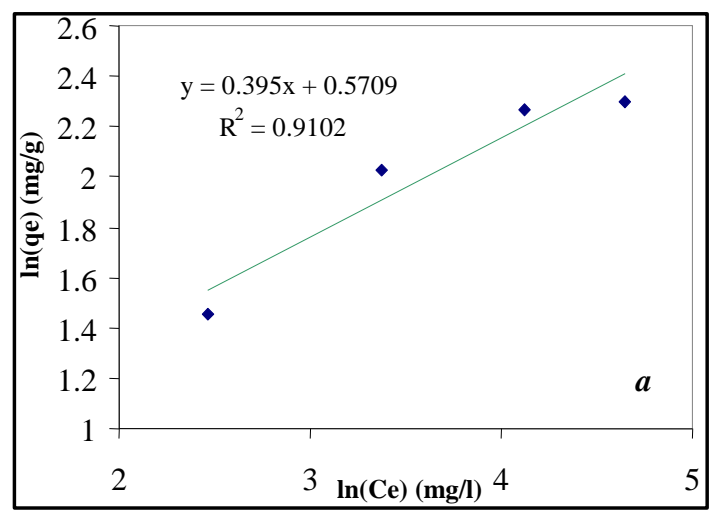

Figure 12. Freundlich adsorption isotherm of Cd (II) onto natural bentonite at $293.15 \mathrm{~K}$.

Table 3. The value of parameters for each isotherm model used at $293.15 \mathrm{~K}$.

\begin{tabular}{cccccccc}
\hline \multirow{2}{*}{ Metal ions } & \multicolumn{3}{c}{ Langmuir model } & \multicolumn{3}{c}{ Freundlich model } \\
\cline { 2 - 7 } & $\mathrm{Q}_{0}\left(\mathrm{mg} \cdot \mathrm{g}^{-1}\right)$ & $\mathrm{B} \times 10^{2}\left(\mathrm{l} \cdot \mathrm{mg}^{-1}\right)$ & $\mathrm{R}_{\mathrm{L}}$ & $\mathrm{r}^{2}$ & $\mathrm{~K}_{\mathrm{F}}\left(\mathrm{mg} \cdot \mathrm{g}^{-1}\right)$ & $\mathrm{n}$ & $\mathrm{r}^{2}$ \\
\hline $\mathrm{Cd}(\mathrm{II})$ & 13.17 & 4.1 & 0.30 & 0.990 & 2.17 & 3.16 & 0.910 \\
$\mathrm{Cr}(\mathrm{VI})$ & 12.61 & 0.56 & 0.77 & 0.997 & 0.17 & 1.42 & 0.979 \\
\hline
\end{tabular}




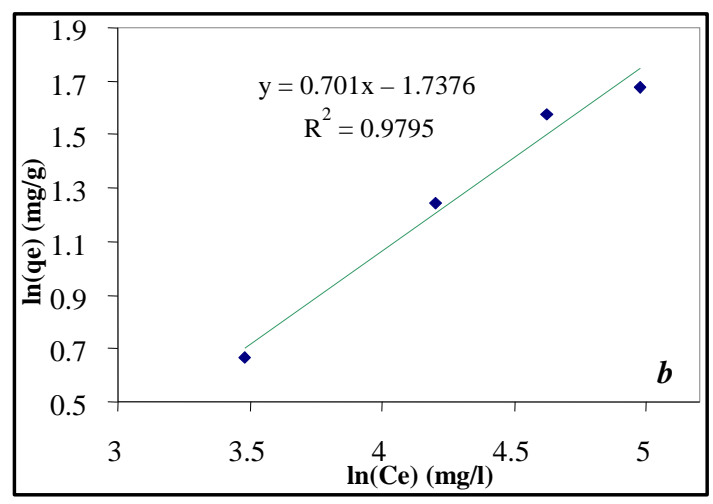

Figure 13. Freundlich adsorption isotherm of Cr (VI) onto natural bentonite at $293.15 \mathrm{~K}$.

Table 4. Kinetic constants (pseudo-first order) for $\mathrm{Cd}$ (II) and $\mathrm{Cr}$ (VI) adsorption at different $\mathrm{pH}$.

\begin{tabular}{ccccccccc}
\hline & \multicolumn{3}{c}{ Kinetic constants (pseudo-first order) for Cd(II) adsorption } & \multicolumn{5}{c}{ Kinetic constants (pseudo-first order) for Cr(VI) adsorption } \\
\hline $\mathrm{pH}$ & $\mathrm{q}_{\mathrm{e}(\mathrm{exp})}\left(\mathrm{mg} \cdot \mathrm{g}^{-1}\right)$ & $\mathrm{q}_{\mathrm{e}(\mathrm{cal})}\left(\mathrm{mg} \cdot \mathrm{g}^{-1}\right)$ & $\mathrm{K}_{1} \times 10^{-2}\left(\mathrm{~min}^{-1}\right)$ & $\mathrm{r}_{1}^{2}$ & $\mathrm{q}_{\mathrm{e}(\mathrm{exp})}\left(\mathrm{mg} \cdot \mathrm{g}^{-1}\right)$ & $\mathrm{q}_{\mathrm{e}(\mathrm{cal})}\left(\mathrm{mg} \cdot \mathrm{g}^{-1}\right)$ & $\mathrm{K}_{1} \times 10^{-2}\left(\mathrm{~min}^{-1}\right)$ & $\mathrm{r}_{1}^{2}$ \\
\hline 0.5 & 6.34 & 5.52 & 2.53 & 0.974 & 2.30 & 2.46 & 2.23 & 0.974 \\
1.0 & 9.28 & 7.08 & 2.579 & 0.980 & 3.22 & 3.58 & 2.41 & 0.980 \\
2.0 & 11.25 & 7.57 & 2.74 & 0.961 & 3.65 & 3.61 & 2.30 & 0.961 \\
3.0 & 11.67 & 8.11 & 2.87 & 0.966 & 4.53 & 4.07 & 2.32 & 0.966 \\
4.0 & 12.29 & 7.70 & 2.51 & 0.982 & 5.35 & 3.93 & 2.12 & 0.982 \\
5.0 & 13.46 & 8.28 & 2.74 & 0.977 & 5.18 & 4.27 & 2.32 & 0.977 \\
6.0 & 14.97 & 9.28 & 2.97 & 0.978 & 5.11 & 4.30 & 2.16 & 0.978 \\
\hline
\end{tabular}

Table 5. Kinetic constants (pseudo-second order) for Cd (II) and $\mathrm{Cr}$ (VI) adsorption at different pH.

\begin{tabular}{ccccccccc}
\hline \multicolumn{7}{c}{ Kinetic constants (pseudo-second order) for Cd(II) adsorption } & \multicolumn{5}{c}{ Kinetic constants (pseudo-second order) for Cr(VI) adsorption } \\
\hline $\mathrm{pH}$ & $\mathrm{q}_{\mathrm{e}(\mathrm{exp})}\left(\mathrm{mg} \cdot \mathrm{g}^{-1}\right)$ & $\mathrm{q}_{\mathrm{e}(\mathrm{cal})}\left(\mathrm{mg} \cdot \mathrm{g}^{-1}\right)$ & $\mathrm{K}_{2} \times 10^{-2}\left(\mathrm{~min}^{-1}\right)$ & $\mathrm{r}_{1}^{2}$ & $\mathrm{q}_{\text {e(exp) }}\left(\mathrm{mg} \cdot \mathrm{g}^{-1}\right)$ & $\mathrm{q}_{\mathrm{e}(\mathrm{cal})}\left(\mathrm{mg} \cdot \mathrm{g}^{-1}\right)$ & $\mathrm{K}_{2} \times 10^{-2}\left(\mathrm{~min}^{-1}\right)$ & $\mathrm{r}_{1}^{2}$ \\
\hline 0.5 & 6.34 & 5.52 & 2.53 & 0.974 & 2.30 & 2.46 & 2.23 & 0.989 \\
1.0 & 9.28 & 7.08 & 2.579 & 0.980 & 3.22 & 3.58 & 2.41 & 0.988 \\
2.0 & 11.25 & 7.57 & 2.74 & 0.961 & 3.65 & 3.61 & 2.30 & 0.977 \\
3.0 & 11.67 & 8.11 & 2.87 & 0.966 & 4.53 & 4.07 & 2.32 & 0.966 \\
4.0 & 12.29 & 7.70 & 2.51 & 0.982 & 5.35 & 3.93 & 2.12 & 0.977 \\
5.0 & 13.46 & 8.28 & 2.74 & 0.977 & 5.18 & 4.27 & 2.32 & 0.984 \\
6.0 & 14.97 & 9.28 & 2.97 & 0.978 & 5.11 & 4.30 & 2.16 & 0.978 \\
\hline
\end{tabular}

Table 6. Kinetic constants (Elovich model) for Cd (II) and $\mathrm{Cr}$ (VI) adsorption at different pH.

\begin{tabular}{ccccccc}
\hline & \multicolumn{2}{c}{ Kinetic constants (Elovich model) for Cd(II) adsorption } & \multicolumn{3}{c}{ Kinetic constants (Elovich model) for Cr(VI) adsorption } \\
\hline $\mathrm{pH}$ & $\beta\left(\mathrm{g} \cdot \mathrm{mg}^{-1}\right)$ & $\alpha\left(\mathrm{mg} \cdot \mathrm{g}^{-1} \cdot \mathrm{min}^{-1}\right)$ & $\mathrm{r}_{1}^{2}$ & $\beta\left(\mathrm{g} \cdot \mathrm{mg}^{-1}\right)$ & $\alpha\left(\mathrm{mg} \cdot \mathrm{g}^{-1} \cdot \mathrm{min}^{-1}\right)$ & $\mathrm{r}_{2}^{2}$ \\
\hline 0.5 & 0.57 & 0.21 & 0.984 & 1.25 & 0.10 & 0.983 \\
1.0 & 0.46 & 0.30 & 0.993 & 0.89 & 0.153 & 0.988 \\
2.0 & 0.45 & 0.42 & 0.987 & 0.78 & 0.33 & 0.980 \\
3.0 & 0.42 & 0.53 & 0.995 & 0.88 & 0.21 & 0.975 \\
4.0 & 0.41 & 0.62 & 0.996 & 0.79 & 0.61 & 0.968 \\
5.0 & 0.39 & 0.75 & 0.997 & 0.74 & 0.47 & 0.982 \\
6.0 & 0.37 & 0.83 & 0.998 & 0.72 & 0.40 & 0.966 \\
\hline
\end{tabular}




\section{Comparison with Other Adsorbents}

In order to justify the validity of the Algerian natural bentonite as an effective adsorbent for Cd (II) and Cr (VI) adsorption, we compared our results with other works carried out elsewhere using other adsorbents for similar purpose. We used as a basis of comparison, the maximum adsorption capacities of Cd (II) and Cr (VI) on different adsorbents. The results are reported in Table 8 including the adsorbent used in this study.

From the results given in Table $\mathbf{8}$, we can observe:

- As for Cd (II), Na-bentonite has a great adsorption capacity $26.2\left(\mathrm{mg}^{-1} \mathrm{~g}^{-1}\right)$ followed by our adsorbent 13.17 $\left(\mathrm{mg} \cdot \mathrm{g}^{-1}\right)$.

- Fe-montmorillonite and bagasse fly ash have the lowest values of adsorption capacities $2.89\left(\mathrm{mg} \cdot \mathrm{g}^{-1}\right)$ and 2.0 $\left(\mathrm{mg} \cdot \mathrm{g}^{-1}\right)$ respectively.

- As for $\mathrm{Cr}(\mathrm{VI})$, micellar compounds has a slightly higher adsorption capacity than ours $17.89\left(\mathrm{mg} \cdot \mathrm{g}^{-1}\right.$ ) and activated carbon (Merck) has the lowest value of adsorption capacity $0.09\left(\mathrm{mg} \cdot \mathrm{g}^{-1}\right)$.

\section{Conclusions}

According to the results obtained in the adsorption process study of Cd (II) and Cr (VI) on natural bentonite, we can conclude that:

- The natural Algerian bentonite used in this study was found to be an effective and low-cost adsorbent for the adsorption of Cd (II) and Cr (VI) ions from aqueous solutions.

- The kinetic experiments show that the adsorption is rapid and maximum efficiencies adsorption achieved in 120 min.

- The $\mathrm{pH}$ of solution has a positive effect, however, the temperature has an inverse effect on adsorption.

- Optimum conditions were found at pH 6 and 5 for Cd (II) and $\mathrm{Cr}(\mathrm{VI})$, a concentration of $50 \mathrm{mg} \cdot \mathrm{L}^{-1}$ and temperature $293.15 \mathrm{~K}$.

- The pseudo first-order, pseudo second-order kinetic and Elovich models were used to analyze data obtained for Cd (II) and Cr (VI) adsorption. The results indicated that the pseudo second-order and Elovich equations provided the best correlation for the adsorption data.

- Langmuir and Freundlich, equilibrium isotherms were used to describe the adsorption of $\mathrm{Cd}$ (II) and $\mathrm{Cr}$ (VI). Langmuir model has better correlation coefficient than Freundlich model.

Table 7. thermodynamic parameters for Cd (II) and Cr (VI) adsorption at the studied temperatures.

\begin{tabular}{|c|c|c|c|c|c|c|c|c|}
\hline & \multirow{2}{*}{$\Delta \mathrm{H}\left(\mathrm{kJ} \cdot \mathrm{mol}^{-1}\right)$} & \multirow{2}{*}{$\begin{array}{c}\Delta \mathrm{S} \\
\left(\mathrm{J} \cdot \mathrm{mol}^{-1} \cdot \mathrm{K}^{-1}\right)\end{array}$} & \multicolumn{6}{|c|}{$\Delta \mathrm{G}\left(\mathrm{kJ} \cdot \mathrm{mol}^{-1}\right)$} \\
\hline & & & $\mathrm{T}=293.15 \mathrm{~K}$ & $\mathrm{~T}=303.15 \mathrm{~K}$ & $\mathrm{~T}=313.15 \mathrm{~K}$ & $\mathrm{~T}=323.15 \mathrm{~K}$ & $\mathrm{~T}=333.15 \mathrm{~K}$ & $\mathrm{~T}=343.15 \mathrm{~K}$ \\
\hline Cd (II) & -20.58 & -17.07 & -15.23 & -15.06 & -14.89 & -14.72 & -14.55 & -14.37 \\
\hline Cr (VI) & -10.10 & -1.26 & -9.70 & -9.69 & -9.68 & -9.67 & -9.65 & -9.64 \\
\hline
\end{tabular}

Table 8. Adsorption capacity of Cd (II) and Cr (III) by various adsorbents.

\begin{tabular}{|c|c|c|c|c|c|}
\hline \multicolumn{3}{|c|}{ Adsorption capacity of Cd(II) by various adsorbents } & \multicolumn{3}{|c|}{ Adsorption capacity of $\mathrm{Cr}(\mathrm{VI})$ by various adsorbents } \\
\hline Adsorbent & $\mathrm{Q}_{0}\left(\mathrm{mg} \cdot \mathrm{g}^{-1}\right)$ & Ref. & Adsorbent & $\mathrm{Q}_{0}\left(\mathrm{mg} \cdot \mathrm{g}^{-1}\right)$ & Ref. \\
\hline Low-grade phosphate & 7.5 & [43] & Bentonite & 0.57 & {$[50]$} \\
\hline Fe-montmorillonite & 2.89 & [44] & Oak sawdust (Quercus coccifera) treated by $\mathrm{HCl}$ & 1.72 & [51] \\
\hline Kaolinite & 9.9 & [45] & Activated carbon (Merck)) & 0.09 & [52] \\
\hline Na-bentonite & 26.2 & {$[46]$} & Activated carbon (BDH) & 0.93 & [53] \\
\hline Red mud & 10.6 & [47] & Iron (III) hydroxide & 0.47 & [54] \\
\hline Bagasse fly ash & 2.0 & [48] & micellar compounds & 17.89 & [55] \\
\hline Ca-bentonite & 7.3 & [49] & Sawdust & 2.29 & [56] \\
\hline Natural Algerian bentonite & 13.17 & Present study & Natural Algerian bentonite & 12.61 & Present study \\
\hline
\end{tabular}


- Thermodynamic analysis showed that the adsorption process was exothermic and spontaneous in nature.

- The sorption capacity of bentonite was comparable to the other available absorbents and it was much cheaper.

\section{References}

[1] Kumarasinghe, D., Pettigrew, L. and Nghiem, L.D. (2009) Removal of Heavy Metals from Mining Impacted Water by an Electrocoagulation-Ultrafiltration Hybrid Process. Desalination and Water Treatment, 11, 66-72. http://dx.doi.org/10.5004/dwt.2009.844

[2] Bansal, M., Singh, D. and Garg, V.K. (2009) Chromium (VI) Uptake from Aqueous Solution by Adsorption onto Timber Industry Waste. Desalination and Water Treatment, 12, 238-246. http://dx.doi.org/10.5004/dwt.2009.937

[3] Rouibah, K., Meniai, A.-H., Rouibah, M.T., Deffous, L. and Bencheikh Lehocine, M. (2010) Chromium VI and Cadmium II Removal from Aqueous Solutions by Olive Stones. Desalination and Water Treatment, 16, 393-401. http://dx.doi.org/10.5004/dwt.2010.1690

[4] Dubey, S.P. and Gopal, K. (2007) Adsorption of Chromium (VI) on Low Cost Adsorbents Derived from Agricultural Waste Material: A Comparative Study. Journal of Hazardous Materials, 145, 312-470. http://dx.doi.org/10.1016/j.jhazmat.2006.11.041

[5] Tahir, S.S. and Naseem, R. (2007) Removal of Cr(III) from Tannery Wastewater by Adsorption onto Bentonite Clay. Separation and Purification Technology, 53, 312-321. http://dx.doi.org/10.1016/j.seppur.2006.08.008

[6] Rao, M., Parwate, A.V. and Bhole, A.G. (2002) Removal of $\mathrm{Cr}^{+}$and $\mathrm{Ni}^{2+}$ from Aqueous Solution Using Bagasse and Fly Ash. Waste Management, 22, 821-830.

[7] Tawn, E.J., Whitehouse, C.A. and Martin, F.A. (2000) Sequential Chromosome Aberration Analysis Following Radiotherapy—No Evidence for Enhanced Genomic Instability. Mutation Research, 465, 45-51. http://dx.doi.org/10.1016/S1383-5718(99)00210-7

[8] Zvinouwanda, C.M., Okonkwo, J.O., Shabalala, P.N. and Agyei, N.M. (2009) A Novel Adsorbent for Heavy Metal Remediation in Aqueous Environments. International Journal of Environmental Science \& Technology, 6, 425-434. http://dx.doi.org/10.1007/BF03326081

[9] World Health Organisation (2004) Guidelines for Drinking-Water Quality. 3rd Edition, Geneva, Vol. 1, 334.

[10] Kannan, N. and Rengasamy, G. (2005) Comparison of Cadmium Ion Adsorption on Various Activated Carbons. Water, Air, and Soil Pollution, 163, 185-201.

[11] Ahn, C.K., Park, D., Woo, S.H. and Park, J.M. (2009) Removal of Cationic Heavy Metal from Aqueous Solution by Activated Carbon Impregnated with Anionic Surfactants. Journal of Hazardous Material, 164, 1130-1136. http://dx.doi.org/10.1016/j.jhazmat.2008.09.036

[12] Jusoh, A., Shiung, L.S., Ali, N. and Noor, M.JM.M. (2007) A Simulation Study of the Removal Efficiency of Granular Activated Carbon and Cadmium and Lead. Desalination, 206, 9-16. http://dx.doi.org/10.1016/j.desal.2006.04.048

[13] Silem, A., Boualia, A., Kada, R. and Mellah (1992) Adsorption of Organic Matter from a Wet Phosphoric Acid Using Activated Carbon: Batch Contact Time Study and Linear Driving Force Models. The Canadian Journal of Chemical Engineering, 70, 491-498.

[14] Sato, S., Yoshihara, K., Moriyama, K., Machida, M. and Tatsumoto, H. (2007) Influence of Activated Carbon Surface Acidity on Adsorption of Heavy Metals Ions and Aromatics from Aqueous Solutions. Applied Surface Science, 235, 8554-8559. http://dx.doi.org/10.1016/j.apsusc.2007.04.025

[15] Chegrouche, S., Mellah, A. and Telmoune, S. (1997) Removal of Lanthanum from Aqueous Solutions by Natural Bentonite. Water Research, 31, 1733-1737. http://dx.doi.org/10.1016/S0043-1354(96)00386-7

[16] Belhachemi, M. and Addoun, F. (2012) Adsorption of Congo Red onto Activated Carbons Having Different Surface Properties: Studies of Kinetics and Adsorption Equilibrium. Desalination and Water Treatment, 37, 122-129. http://dx.doi.org/10.1080/19443994.2012.661263

[17] Barkat, M., Nibou, D., Chegrouche, S. and Mellah, A. (2009) Kinetics and Thermodynamics Studies of Chromium (VI) Ions Adsorption onto Activated Carbon from Aqueous Solutions. Chemical Engineering and Processing: Process Intensification, 48, 38-47. http://dx.doi.org/10.1016/j.cep.2007.10.004

[18] Jha, I., Iyengar, L. and Rao, A.P. (1988) Removal of Cadmium Using Chitosan. Journal of Environmental Engineering, 114, 964-974. http://dx.doi.org/10.1061/(ASCE)0733-9372(1988)114:4(962)

[19] Langmuir, I. (1918) The Adsorption of Gases on Plane Surfaces of Glass, Mica and Platinu. Journal of the American Chemical Society, 40, 1361-1403.

[20] Freundlich, H.M.F. (1907) Uber Die Adsorption in Losungen. Zeitschrift für Physikalische Chemie, 57, 385-470. 
[21] Nibou, D., Mekatel, H., Amokrane, S., Barkat, M. and Trari, M. (2010) Adsorption of $\mathrm{Zn}^{2+}$ Ions onto NaA and NaX Zeolites: Kinetic, Equilibrium and Thermodynamic Studies. Journal of Hazardous Materials, 173, 637-646. http://dx.doi.org/10.1016/j.jhazmat.2009.08.132

[22] Lagergren, S. (1898) About the Theory of So-Called Adsorption of Soluble Substances. Kungliga Svenska Vetenskapsakademiens, 24, 1-39.

[23] Ho, Y.S. and McKay, G. (1999) Pseudo-Second Order Model for Sorption Processes. Process Biochemistry, 34, 451465. http://dx.doi.org/10.1016/S0032-9592(98)00112-5

[24] Ho, Y.S. and McKay, G. (2002) Application of Kinetic Models to the Sorption of Copper(II) onto Peat. Adsorption Science \& Technology, 20, 797-815. http://dx.doi.org/10.1260/026361702321104282

[25] Duran, C., Ozdes, D., Gundogdu, A. and Senturk, H.B. (2011) Kinetics and Isotherm Analysis of Basic Dyes Adsorption onto Almond Shell (Prunus dulcis) as a Low Cost Adsorbent. Journal of Chemical Engineering Data, 56, 21362214.

[26] Chen, S., Yue, Q., Gao, B., Li, Q. and Xu, X. (2011) Removal of Cr(VI) from Aqueous Solution Using Modified Corn Stalks: Characteristic, Equilibrium, Kinetic and Thermodynamic Study. Chemical Engineering Journal, 168, 909-917. http://dx.doi.org/10.1016/j.cej.2011.01.063

[27] Huang, R., Wang, B., Yang, B., Zheng, D. and Zhang, Z. (2011) Equilibrium, Kinetic and Thermodynamic Studies of Adsorption of Cd(II) from Aqueous Solution onto HACC-Bentonite. Desalination, 280, 297-304. http://dx.doi.org/10.1016/j.desal.2011.07.033

[28] Adebowale, K.O., Unuabonah, I.E. and Olu-Owolabi, B.I. (2006) The Effect of Some Operating Variables on the Adsorption of Lead and Cadmium Ions on Kaolinite Clay. Journal of Hazardous Materials, 134, 130-139. http://dx.doi.org/10.1016/j.jhazmat.2005.10.056

[29] Mellah, A. and Chegrouche, S. (1997) The Removal of Zinc from Aqueous Solutions by Natural Bentonite. Water Research, 31, 621-629. http://dx.doi.org/10.1016/S0043-1354(96)00294-1

[30] Zeid, A., Othman, A., Hashem, A. and Habila, A. (2011) Kinetic, Equilibrium and Thermodynamic Studies of Cadmium(II) Adsorption y Modified Agricultural Wastes. Molecules, 16, 10443-10456.

[31] Abollino, O., Aceto, M., Malandrino, M., Sarzanini, C. and Mentasti, E. (2003) Adsorption Heavy Metals on NaMontmorillonite. Effect of pH and Organic Substances. Water Research, 37, 1619-1627. http://dx.doi.org/10.1016/S0043-1354(02)00524-9

[32] Bhattacharya, A.K., Mandal, S.N. and Das, S.K. (2006) Adsorption of Zn(II) from Aqueous Solution by Using Different Adsorbents. Chemical Engineering Journal, 123, 43-51. http://dx.doi.org/10.1016/j.cej.2006.06.012

[33] Low, K.S., Lee, C.K. and Lee, K.P. (1993) Sorption of Copper by Dye-Treated Oil-Palm Fibers. Bioresource Technology, 44, 109-112. http://dx.doi.org/10.1016/0960-8524(93)90183-C

[34] Ucun, H., Bayhan, Y.K., Kaya, Y., Çakici, A. and Algur, O.F. (2002) Biosorption of Chromium(VI) from Aqueous Solution by Cone Biomass of Pinus sylvestris. Bioresource Technology, 85, 155-158. http://dx.doi.org/10.1016/S0960-8524(02)00086-X

[35] Azouaou, N., Sadaoui, Z., Djaafri, A. and Mokaddem, H. (2010) Adsorption of Cadmium from Aqueous Solution onto Untreated Coffee Grounds: Equilibrium, Kinetics and Thermodynamics. Journal of Hazardous Materials, 184, 126134. http://dx.doi.org/10.1016/j.jhazmat.2010.08.014

[36] Hosseini-Bandegharaei, A., Hosseini, M.S., Sarw-Ghadi, M., Zowghi, S., Hosseini, E. and Hosseini-Bandegharaei, H. (2010) Kinetics, Equilibrium and Thermodynamic Study of Cr(VI) Sorption into Toluidine Blue o-Impregnated XAD7 Resin Beads and Its Application for the Treatment of Wastewaters Containing Cr(VI). Chemical Engineering Journal, 160, 190-198. http://dx.doi.org/10.1016/j.cej.2010.03.040

[37] Pérez-Marín, A.B., Zapata, V.M., Ortuño, J.F., Aguilar, M., Sáez, J., Lloréns, M. and Hazard, J. (2007) Removal of Cadmium from Aqueous Solutions by Adsorption onto Orange Waste. Journal of Hazardous Materials, 139, 122-131. http://dx.doi.org/10.1016/j.jhazmat.2006.06.008

[38] Sen, T.K. and Sarzali, M.V. (2008) Removal of Cadmium Metal Ion $\left(\mathrm{Cd}^{2+}\right)$ from Its Aqueous Solution by Aluminium oxide $\left(\mathrm{Al}_{2} \mathrm{O}_{3}\right)$ : A Kinetic and Equilibrium Study. Chemical Engineering Journal, 142, 256-262. http://dx.doi.org/10.1016/j.cej.2007.12.001

[39] Semerjian, L. (2010) Equilibrium and Kinetics of Cadmium Adsorption from Aqueous Solutions Using Untreated Pinus halepensis Sawdust. Journal of Hazardous Materials, 173, 236-242.

[40] Elangovan, R., Philip, L. and Chandraraj, K. (2008) Biosorption of Chromium Species by Aquatic Weeds: Kinetics and Mechanism Studies. Journal of Hazardous Materials, 152, 100-112. http://dx.doi.org/10.1016/j.jhazmat.2007.06.067

[41] Gode, F. and Pehlivan, E. (2005) Adsorption of Cr(III) Ions by Turkish Brown Coals. Fuel Processing Technology, 86, 875-884. http://dx.doi.org/10.1016/j.fuproc.2004.10.006 
[42] Sari, A., Mendil, D., Tuzen, M. and Soylak, M. (2008) Biosorption of Cd(II) and Cr(III) from Aqueous Solution by Moss (Hylocomium splendens) Biomass: Equilibrium, Kinetic and Thermodynamic Studies. Chemical Engineering Journal, 144, 1-9. http://dx.doi.org/10.1016/j.cej.2007.12.020

[43] Kandah, M.I. (2004) Zinc and Cadmium Adsorption on Low-Grade Phosphate. Separation and Purification Technology, 35, 61-70. http://dx.doi.org/10.1016/S1383-5866(03)00131-X

[44] Wu, P., Wu, W., Li, S., Xing, N., Zhu, N., Li, P., Wu, J., Yang, C. and Dang, Z. (2009) Removal of Cd ${ }^{2+}$ from Aqueous Solution by Adsorption Using Fe-Montmorillonite. Journal of Hazardous Materials, 169, 824-830. http://dx.doi.org/10.1016/j.jhazmat.2009.04.022

[45] Gupta, S. and Bhattacharyya, K.G. (2006) Removal of Cd(II) from Aqueous Solution by Kaolinite, Montmorillonite and Their Poly(Oxo Zirconium) and Tetrabutylammonium Derivatives. Journal of Hazardous Materials, 128, 247-257. http://dx.doi.org/10.1016/j.jhazmat.2005.08.008

[46] Alvarez-Ayuso, E. and Garcia-Sanchez, A. (2003) Removal of Heavy Metals from Waste Waters by Natural and NaExchanged Bentonites. Clays and Clay Minerals, 51, 475-480. http://dx.doi.org/10.1346/CCMN.2003.0510501

[47] López, E., Soto, B., Arias, M., Núñez, A., Rubinos, D. and Barral, M.T. (1998) Adsorbent Properties of Red Mud and Its Use for Wastewater Treatment. Water Research, 32, 1314-1322. http://dx.doi.org/10.1016/S0043-1354(97)00326-6

[48] Gupta, V.K., Jain, C.K., Ali, I., Sharma, M. and Saini, V.K. (2003) Removal of Cadmium and Nickel from Wastewater Using Bagasse Fly Ash-A Sugar Industry Waste. Water Research, 37, 4038-4044. http://dx.doi.org/10.1016/S0043-1354(03)00292-6

[49] da Fonseca, M.G., de Oliveira, M.M. and Arakaki, L.N.H. (2006) Removal of Cadmium, Zinc, Manganese and Chromium Cations from Aqueous Solution by a Clay Mineral. Journal of Hazardous Materials, 137, 288-292. http://dx.doi.org/10.1016/j.jhazmat.2006.02.001

[50] Khan, S.A., Rehman, R. and Khan, M.A. (1995) Adsorption of Chromium(III), Chromium(VI) and Silver(I) on Bentonite. Waste Management, 15, 271-282. http://dx.doi.org/10.1016/0956-053X(95)00025-U

[51] Argun, M.E., Dursun, S., Ozdemir, C. and Karatas, M. (2007) Heavy Metal Adsorption by Modified Oak Sawdust: Thermodynamics and Kinetics. Journal of Hazardous Materials, 141, 77-85. http://dx.doi.org/10.1016/j.jhazmat.2006.06.095

[52] Gupta, G.S., Prasad, G. and Singh, V.N. (1990) Removal of Chrome Dye from Aqueous Solutions by Mixed Adsorbents: Fly Ash and Coal. Water Research, 24, 45-50. http://dx.doi.org/10.1016/0043-1354(90)90063-C

[53] Khambhaty, Y., Mody, K., Basha, S. and Jha, B. (2009) Kinetics, Equilibrium and Thermodynamic Studies on Biosorption of Hexavalent Chromium by Dead Fungal Biomass of Marine Aspergillus niger. Chemical Engineering Journal, 145, 489-495. http://dx.doi.org/10.1016/j.cej.2008.05.002

[54] Namasivayam, C. and Ranganathan, K. (1992) Waste Fe(III)/Cr(III) Hydroxide as Adsorbent for the Removal of Cr(VI) from Aqueous Solution and Chromium Plating Industry Wastewater. Environmental Pollution, 82, 255-261. http://dx.doi.org/10.1016/0269-7491(93)90127-A

[55] Sadaoui, Z., Hemidouche, S. and Allalou, O. (2009) Removal of Hexavalent Chromium from Aqueous Solutions by Micellar Compounds. Desalination, 249, 768-773. http://dx.doi.org/10.1016/j.desal.2009.02.062

[56] Noonpui, S., Thiravetyan, P., Nakbanpote, W. and Netpradit, S. (2010) Color Removal from Water-Based Ink Wastewater by Bagasse Fly Ash, Sawdust Fly Ash and Activated Carbon. Chemical Engineering Journal, 162, 503-508. http://dx.doi.org/10.1016/j.cej.2010.05.051 
Scientific Research Publishing (SCIRP) is one of the largest Open Access journal publishers. It is currently publishing more than 200 open access, online, peer-reviewed journals covering a wide range of academic disciplines. SCIRP serves the worldwide academic communities and contributes to the progress and application of science with its publication.

Other selected journals from SCIRP are listed as below. Submit your manuscript to us via either submit@scirp.org or Online Submission Portal.
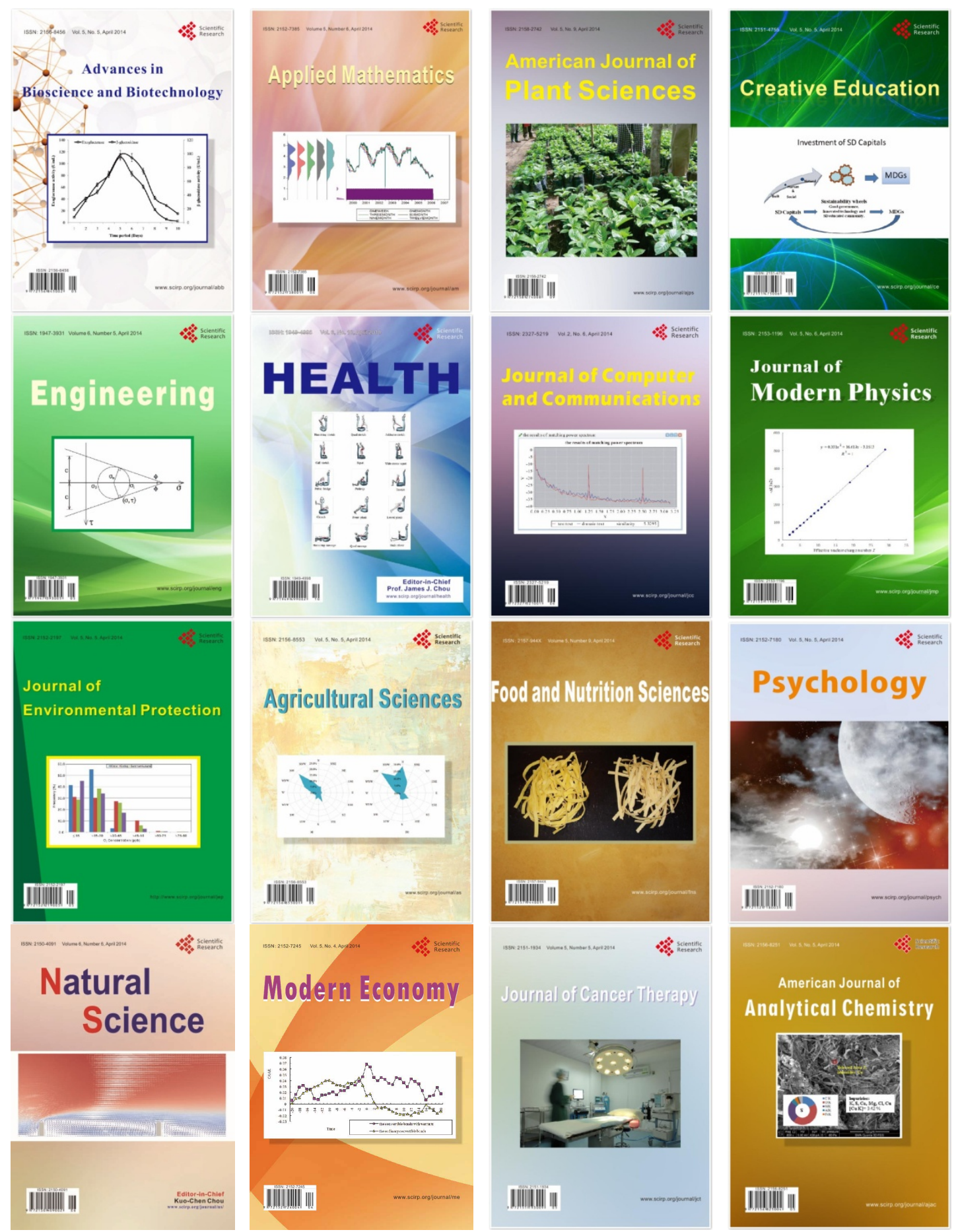